\title{
Construction of Think Tank Relying on Universities
}

\author{
Yong Tao, Qiusih Li, Gang Zhao, Wen Zhao \\ National Laboratory on Aerospace/The Chinese Institute of Aeronautical Engineering Development \\ Strategies \\ Beihang Univerisy \\ Beijing, China \\ e-mail: taoy@buaa.edu.cn
}

Keywords: think tanks; university characteristic; connotation; think tanks consciousness; consulting services

\begin{abstract}
Think tanks in universities conduct prospective, strategic and overall research on the major issues of economic and social development, which can provide intellectual support for the national scientific decision-making. This paper analyzes the connotation, the necessity and the current situation of think tanks in universities and puts forward promoting the construction of university characteristic think tanks comprehensively from the perspective of strengthening thinktank consciousness and building high-end strategy consulting personnel, collaborative innovation, setting up think tanks union, broadening publicity channels and strengthening international exchanges and cooperation.
\end{abstract}

\section{Introduction}

The Chinese Communist Party's 18th national congress puts forward "adhere to the scientific decision-making, democratic decision-making, decision-making according to law, improve the decision-making mechanisms and procedures and play the role of think banks", which fully reflects that the decision-making mechanism in China develops toward scientification, democratization and institutionalization. It not only greatly enhances information transparency of decision-making, but also shows that the demand for specialized knowledge, international experience and policy evaluation, required by scientific decision-making is more urgent.

Facing national requirement of decision-making, the role and importance of think tanks is increasing. Provide guiding, strategic and forward-looking development strategies, ideas and policy recommendations about the economic and social development, major engineering demonstration and people's livelihood and scientific and technological development in the country.

Under the general background of China's economic development adapting to the new normality and facing the transformation and upgrading, the think tanks in universities have become an important symbol for research universities serving national development, and the construction of a number of Chinese characteristic high-end think tanks with international vision and based on the native culture has become strategic choice for many research universities. High-level experts is the key for think tanks to generate high quality innovative research results, which is the important guarantee for playing talents convergence effects to form long-term mechanism for consultative governance suggestions, as well as the fundamental support for promoting think tanks to exert policy influence to improve service level

\section{Connotation and Significance of Think Tank in Universities}

\section{Connotation}

Think Tank refers to the public institutions which give advice and suggestions for decisionmakers when handling with the social, economic, technological, military and diplomatic, etc. 
development and provide the best theories, strategies, methods, ideas, etc., which are made up of multidisciplinary experts [1]. As think bank, think tank is an organization producing knowledge and ideas. The innovative ideas and innovative concepts are its most important outputs [2]. Think tank in universities focuses on major issues, serves national strategy, adheres to being truthful and practical and enthusiastic and forms forward-looking, strategic, targeted and operational research results, which can provide high-quality intellectual support for scientific decision-making of the government, as well as advisors for decision scheme of the reform and development, evaluators for policy effectiveness and guiders for public opinion [3].

Think tank in universities studies the issue independently and objectively and makes recommendations by freely exploring research direction, conducts in-depth research based on prospective and strategic issues, and fully reflects its function of serving the community development. The enhancement of the ability of serving the society reflects the commitment of universities to social responsibility. Meanwhile, the construction of think tanks is conductive to personnel training mode of universities and improving personnel training quality [4]. The construction of think tanks in universities, the enhancement of the ability to serve the community and the improvement of personnel training quality form the virtuous circle.

Think tank in universities plays its role and form brand effect through its research results and provide suggestions, such as policy ideas and schemes, etc. and consulting research report for relevant government departments. Think tanks in universities have a set of channels and mechanisms for playing role and forming influence, such as comments on social hot issues, organizing high-level forums and seminars and holding international academic conferences and exchanges. The formation of influential think tank in universities is the comprehensive reflection of policy influence, social influence and international influence.

\section{Necessity for the Construction of Think Tanks in Universities}

Create high-end think tank with important influence at home and abroad relying on universities. As Chinese characteristic new think tank, its main characteristics and role is to: serve the country and people, world-class specialization and professionalization, provide ideas for China, provide humanity with wisdom and make significant knowledge contribution.

Think tank in universities supports national scientific decision, the right to speak in the international and enhances the country's soft power. Firstly, strengthen the construction of think tank in universities and build the bridge between schools and government, knowledge and decisionmaking, which is conducive to converting academic strengths in universities into the advantages of scientific policy research; Secondly, when facing science and technology of the national key projects and social hot issues, think tank in universities takes advantages in giving play to engineering demonstration, risk aversion and progress assessment; Thirdly, think tank is an important symbol of national soft power. The construction of think tanks in universities is not only conducive to building international promotion and propaganda of world-class universities, but also conducive to improving China's international discourse right and enhancing the comprehensive national strength [5-6].

\section{Construction Situation of Chinese Characteristic Think Tank}

In January 2014, the think tank research project of the University of Pennsylvania issued the “Global Think Tank Development Report in 2013” in the World Bank and the United Nations Headquarters. The report shows that there were 6826 think tanks in the world in total in 2013, and China ranked second with 426 think tanks in the world; however, among the world's top 100 important think tanks, there are six Chinese think tanks entering finalists, namely CASS, China Institute of Contemporary International Relations, China Institute of International Studies, CSIS, Shanghai Institutes for International Studies and the State Development Research Center [7]. In the rank of top 40 best think tanks in universities in the world, there are only two think tanks in universities belonging to China, which respectively ranks No. 7, the Tsinghua-Brookings Research Center for Public Policy, and No. 13, the Institute of International Relations of Peking University, and there are more than 11 US think tanks among them.

According to Chinese think tank report in 2013, Chinese think tanks are divided into four categories, government, military and political think tank, think tank of Academy of Social Sciences, 
think tank in universities and folk think tank. The 2/5 of our active think tank is government, military and political think tank, where "GuoZiHao" think tank accounts for about 30\% of government and political think tank [8]. In terms of quality, the think tanks in universities account for a third of the total quality of think tanks in the country; In terms of form, the vast majority of colleges and universities have created research institutions; the research institutions of part of "985", "211" universities effectively play the role of think tank and have a certain social impact. For other many universities, teaching is still the main task. Scientific research work is mainly based on theoretical research, so its role of serving local economic and social development is limited [9].

From the perspective of strategic overall situation of think tank development perspective in China, think tanks in universities play the role of think tanks. The relevant consulting research areas have the following advantages: Firstly, universities have gathered more than $80 \%$ of social science researchers and nearly half of academicians. The majority of universities have considerable doctors and postgraduate, its personnel support for think tank construction cannot be compared by other agencies or departments; Secondly, the discipline categories of universities are wide, natural sciences overlaps social sciences, which is conducive to cross-disciplinary and interdisciplinary synthetic judgment problem; Thirdly, colleges and universities facilities are complete, basic research strength is strong. Theoretical depth can be increased in think tank construction to improve the decisionmaking level. Finally, colleges and universities can establish the most extensive link with universities at home and abroad and research institutions, so as to expand the horizons for think tank construction and form international academic network easily.

\section{Consideration and Suggestions for the Construction of Think Tank in Universities}

Establish Chinese characteristic new think tanks relying on universities, benchmark with worldclass think tank, catch up from behind and narrow the gap. From the nature of think tanks, be base on China's national conditions, which can provide support for scientific decision-making of the Party Central Committee, the State Council and the relevant ministries. Be worry about what the nation is worry about, think what the nation thinks and the country's future and realize "the knowledge for people and knowledge serving the country" of think tanks in universities.

The construction of think tanks in universities should achieve specialization and professionalism, realize innovative ideas and organization form through long-term accumulation, output consulting suggestion and research reports with excellent quality and effect, provide high quality solutions and output consulting research results with depth and influence.

\section{Enhancing Think Tank Consciousness and Improving the Ability to Develop Strategic Consulting}

Service

Establish the think tank consciousness, cultivate the enthusiasm for serving government decisionmaking actively, correct attitudes and properly understand the importance and necessity of this work. Guided by the relevant policies and development guidelines of the government, focus on serving government decision-making and quality of economic development, strengthen suffering consciousness, opportunity awareness and sense of competition, change research concepts and constantly improve the service level of decision-making consulting; tightly center on the development goals and key fields, seize key nodes, target major national needs, establish the urgent research and consulting issues, especially for forward-looking and systematic major issues with timeliness in the economic and social development, conduct consulting research, put forward high quality development suggestion and report; establish the key research areas of think tank in universities based on preponderant discipline in universities, realize characteristic development, focus on establishing multi-level and multi-form professional, industrial and comprehensive think tank.

\section{Strengthening the Construction of High-end Talent Team of Think Tank in Universities and Creating Specialized Strategic Consulting Team}

The construction of new think tank in universities should take talents as its most important resource and support, take specialized talent team as the core and gather a number of high-end talent with high academic attainments, who are good at linking theory with practice and familiar with the decision-making process; improve scientific research team echelon construction, give full play to the 
role of teaching and mentoring of academicians and experts in universities, strengthen the cultivation of youth core academic reserve and conduct research on overall, strategic and forward-looking hot spots and difficulties [10-11]; by organizing high-level forum and holding high-level academic reports and other forms, strengthen the contact, exchange and cooperation with experts and scholars in various think tanks and various fields of economic and social development at home and abroad, learn from each other, improve together and offer advice and suggestions for the central and local departments.

\section{Giving Play to Collaborative Innovation Advantage and Building the Think Tank Union in Universities}

The construction of think tank in universities is through the integration and sharing of resources and the establishment of comprehensive, long-term and stable cooperative relationship between universities and international, universities and enterprises, universities government. Through the establishment of inter-departmental research team, form research community and realize multiscience, multi-disciplinary, multi-field talent gather and the organic integration of innovative elements, give play to collaborative advantage, cooperate mutually, broaden research perspective, tackle a critical point jointly, improve the quality of results, the targeted and operability of research results will be stronger and closer to the decision-making needs to make research results more scientific and serve for government decision-making better [12-13]. For example, China Strategy Research Institute of Aeronautical Engineering Science and Technology Development jointly established by Beihang University and the Chinese Academy of Engineering cooperates with aviation backbone enterprises, such as AVIC and COMAC, to carry out strategic consulting research around major engineering problems in aerospace filed, so as to build the national characteristic think tank in aerospace filed in our country.

\section{Strengthening Propaganda and Expanding the Social Influence}

Think tanks in universities should expand information dissemination channels and improve result publishing platform. Exchanges can be conducted through the publication of monographs, periodicals, research reports and brief reports and by holding academic seminars, forums, international conferences, seminars and training courses, accepting media interviews, issuing current event hot spot essay in newspapers and websites and public comments, etc. Strengthen the exchanges with the community through new media, such as official microblog and WeChat, etc. [14], influence public opinion, establish public image and constantly expand the penetration and influence of think tanks in universities on society.

\section{Strengthening International Exchanges and Cooperation, Enhancing the International Influence}

The construction of think tank in universities adheres to being based on China and moving toward the international. Actively carry out exchanges and cooperation with the internationally renowned think tanks. Through the forms, such as organizing international forums, conducting subject research by cooperation with foreign think tanks and selecting scholars to further study and access to foreign think tanks and by learning from and absorbing advanced management experience and research methods of foreign think tanks, improve the international forefront and strategic foresight of research [15], establish public confidence, win international discourse right and strive to build high-level think tank with global awareness and international perspective and make contribution to enhancing the soft power in our country.

\section{Conclusion}

In this paper, the author takes the construction of university characteristic think tank as the research object, sets forth the connotation, characteristics and necessity of think tank in universities, comprehensively analyzes the current situation, strengths and weaknesses of think tank construction in universities. In order to give full play to the important functions of university characteristic think tanks in strategic research, policy recommendations, personnel training, public opinion guidance and public diplomacy, think tanks need to strengthen awareness, a clear positioning, strengthen think tank consciousness, clear position, highlight emphasis and characteristics, serve development strategy, gather high-end talents, innovate collaboratively, expand the publicity channels of results, 
actively carry out international exchanges and cooperation and comprehensively promote the construction of university characteristic think tanks.

\section{Acknowledgment}

Thank you for the support of strategic consulting research project of Chinese Academy of Engineering.

\section{References}

[1] Yu J. China Think Tank Development Report System Construction of the Think Tank Industry [M]. Red Flag Publishing House, 2012.

[2] Xu Xiaohu, Chen Qi. Development Process and Prospect of Think Tank [J]. Forum on Science and Technology in China, 2012, No.7: 63-38.

[3] Liu yandong. Playing a unique advantage in Colleges and Universities and Building a new think tank with Chinese characteristics [J]. ZhongGuo Jiaoyu Bao. 2013,11:83.

[4] Ma HQ. Building a new type of University think-tank and service for the scientific decisionmaking--- Visit to the Ministry of education, Social Sciences Division, Zhang Donggang [J]. Chinese University Technology Transfer, 2014, 04:12-14.

[5] Hu AnGang. Building a new think tank with Chinese characteristics [J]. Tsinghua Journal of Education,2013, 5: 1-4.

[6] Hu Angang. Building New Think Tanks with Chinese Features : Practice and Summary [J]. The Journal of Shanghai Administration Institute, 2014.25:4-11.

[7] Think-tank Research Center of Shanghai Academy of Social Sciences, research center, 2013 Global Think-tank Report [R].2013.

[8] Think-tank Research Center of China Science and Technology Information, 2013 China think tank report - influence ranking and policy recommendations [J], China Science and Technology Information, 2014,11.

[9] Chinese Academy of Science and Technology for Development, Statistical survey of the National Soft Science Research Institute of 2009-2010[R], Beijing, 2011.

[10] Wei Z, Chen G. The Current Situation of the Construction of Chinese New Think Tanks and the Approaches of Improvement [J]. Education Science, 2014, 03: 66-70.

[11] Xu XH, Chen X. Study on the Operation Mechanism of the Local Think-tank -- An Empirical Study Based on the Think-tank [J]. Journal of Nanjing University ( Philosophy, Humanities and Social Sciences),2012,05:21-28.

[12] Wang L, WU WQ. A Logical Analysis of the Think Tank Construction in Local Universities: Based on Exploration of the Innovation in Local Government Administration [J]. Tsinghua Journal of Education, 2013, 6: 109-114.

[13] Yang J, Chen Y. Reasearch on the construction of University think-tank under theory of Cooperative Innovation [J]. Science \& Technology Progress \& Policy, 2015, 07: 7-11.

[14] Gao ZQ. [J]. Attributes and Development Strategies of Local University Think-tank [J]. Higher Education Development and Evaluation, 2014, 03: 37-43.

[15] [Li W. Thinking about the Construction of University Think-tank [J]. Science \& Technology Information, 2013, 27: 200-201. 